UDC 621.39:004.724

\title{
NEW GENERATION NETWORKS STRUCTURAL SYNTHESIS WITH APPLICATION OF MODIFIED GENETIC ALGORITHM
}

\author{
Yuriy Zaychenko, Helen Zaychenko \\ Institute for Applied System Analysis \\ National Technical University of Ukraine "Igor Sikorsky Kyiv Politechnic Institute”, Kyiv, Ukraine
}

\begin{abstract}
Background. The problem of new generation computer network structural synthesis is considered under constraints on Quality of Service (QoS) - average packets transfer delay (PTD) and packets loss ratio (PLR). Besides network structure it is necessary to determine simultaneously channels capacities and find flow distribution for all classes of service (customers). This problem refers to so-called NP-difficult combinatorial optimization problems for which there are no exact algorithms of polynomial computational complexity. Therefore in the paper modified genetic algorithm (GA) is suggested for its solution.
\end{abstract}

Objective. The aim of the paper is to investigate different modifications (variants) of genetic algorithms: deterministic, adaptive and self-adjusted and estimate their efficiency for the solution of the considered problem.

Methods. Based on analysis of literature on GA classes of algorithms were detected differed by variants of strategic parameters adaptation - probabilities of crossover and mutations. Different combinations of adaptation methods were implemented and analyzed - deterministic, adaptive and self- adjusting.

Results. The following variants of GA were investigated in the research:

- the combination of unconditional crossover and dynamic deterministic mutation;

- $\quad$ the combination of unconditional crossover and dynamic adaptive mutation;

- $\quad$ the combination of unconditional crossover and dynamic self-adjusting mutation;

- the combination dynamic deterministic crossover and dynamic mutation;

- the combination dynamic adaptive crossover an unconditional mutation.

Conclusions. In result of investigations it was established that the most efficient for the computer networks structural synthesis is the genetic algorithm with combination of dynamic adaptive crossover an unconditional mutation. This algorithm was implemented in software kit and applied for real problem of NG network structural design and its efficiency was estimated.

Keywords: New generation networks; Quality of Service; structure synthesis; adaptive genetic algorithm.

\section{Introduction}

One of the most perspective class of networks is new generation network (NGN). NGN uses different classes of service $(\mathrm{CoS})$ for transmission of various information types (data, audio and video) and assures the corresponding quality of service (QoS) for corresponding CoS. QoS indices include the following factors: Packets Delay Time ( PDT), Packets delay Variance (PDV) and Packets Loss Ratio (PLR). NG networks are mostly based on MPLS technology (Multiprotocol Label Switching)

The important feature of NGN is that it's easily integrates with Internet protocol stack TCP/IP.

The appearance of NG networks technology had demanded development of NG networks optimal design methods which would take into account the specificity of MPLS technology

One of the important design problems of NG network is the problem of optimal structure synthesis under constraints on given values of QoS. This problem for MPLS networks was firstly considered and genetic algorithm (GA) for its solution was suggested in [1].
But this algorithm implemented only two operators of GA: mutations and selection while the operator crossover wasn't implemented. Besides the mutations probability was fixed and wasn't adapted in the search process.

Therefore the problem has arisen to modify the initial GA for GN network structural synthesis and create more efficient adaptive algorithm including all genetic operators.

The main goal of this paper is to elaborate the adequate genetic algorithm for NG networks structure optimization and investigate its efficiency.

\section{Problem statement}

Let's consider the problem of computer network structure optimization with MPLS technology [1] A set of networks nodes (so-called LSR (Label Switching Routers) $X=\left\{x_{j}\right\} \quad j=\overline{1, n}$ - is given, their locations over territory, a set of channels $D=\left\{d_{1}, d_{2}, \ldots, d_{k}\right\}$ and their costs per unit length 
$C=\left\{c_{1}, c_{2}, \ldots, c_{k}\right\}, \operatorname{CoS}$ (Class of Service) are defined, matrices of incoming demands are known for each class of service $H(k)=\left\|h_{i j}(k)\right\| i, j=\overline{1, n}$; $k=1,2, \ldots, K$, where $h_{i j}(k)$ is the k-th class flow rate which is to be transmitted from node $\mathrm{i}$ to node $\mathrm{j}$ (Mbits/sec).

For obtaining analytical models for QoS PTD and PLR of $k$-th priority class the following assumptions are introduced:

- Input flows in nodes of all classes are Poisson with intensity $h_{i j}^{(k)}$.

- Service time in channels $(r, s)$ is distributed by exponential law with parameter intensity $\mu_{r s}$ (Mbit/s), where $\mu_{r s}$ is capacity of the channel $(r, s)$.

- Service time of a packet in different channels is statistically independent random variable.

Under such assumptions using queue theory the following formula was obtained for average delay of $k$-th priority flow in a network [1]:

$$
T_{c p, k}=\frac{1}{H_{\Sigma}^{(k)}} \sum_{(r, s) \in E} \frac{f_{r s}^{(k)} \sum_{i=1}^{k} f_{r s}^{(i)}}{\left(\mu_{r s}-\sum_{i=1}^{k-1} f_{r s}^{(i)}\right) \cdot\left(\mu_{r s}-\sum_{i=1}^{k} f_{r s}^{(i)}\right)},
$$

where $H_{\Sigma}^{(k)}=\sum_{j=1}^{n} \sum_{i=1}^{n} h_{i j}^{(k)}$ is total intensity of input flow of the $k$ - th priority (class):

$f_{r s}^{(i)}$ is the flow of i-th priority in the $(r, s)$.

The probability of packets loss of the $k$-th class (priority) is equal to the probability of the state when all the virtual channels allotted for $k$-th class of flow in the channel $(r, s)$ are occupied is determined in [1]:

$P_{n o m r, s}^{(k)}=P_{0} \cdot\left(\frac{f_{r s}^{(k)}}{\mu}\right)^{n_{k}} \cdot \frac{1}{n_{k} !} \cdot\left(\frac{f_{r s}^{(k)}}{n_{k} \mu}\right)^{N_{k}}$,

where $\mu$ - capacity of the base channel, e.g., $\mu_{1}=2.048 \frac{\text { Mbit }}{s}$;

$n_{k}$ - a number of channels in the $\operatorname{link}(r, s)$ allotted for transmission of the $k$-th flow;

$N_{k}$-a buffer size in LSR assigned for queue of $k$-th class of packets;

$P_{0}$ - a normalizing multiplier.

Then the loss ratio of the- $k$-th class of packets will be equal to:

$$
P L R_{k}=1-\prod_{(r, s) \in E}\left(1-P_{n o m \cdot(r, s)}^{(k)}\right)
$$

Let desired values of QoS be set at average packet time delay $T_{\text {зад, } k}$ and packets loss ratio for each $\operatorname{CoS}$ $P L R_{\text {зад }, k}, k=\overline{1, K}$

It's required to determine MPLS network structure as a set of channels, to find their capacities $\left\{\mu_{r s}\right\}$ and flows distribution for each class $F(k)=\left[f_{r s}(k)\right]$ so that to enable to transmit all the classes demands $H(k)$ with average packet time delay $T_{c p}$ not exceeding given values $T_{3 a \partial, \kappa}$ and Packets Loss ratio (PLR) not exceeding limitation on this value $\operatorname{PLR}_{k, \text { зад }}$ and total network cost should be minimal [1]

Let's construct a math model of this problem. It's necessary to find such network structure E, for which:

$$
\min C_{\Sigma}=\sum_{(r, s) \in E} C_{r s}\left(\mu_{r s}\right)
$$

under constraints

$$
\begin{gathered}
T_{c p, \kappa}\left(F(k), \mu_{r s}\right) \leq T_{\text {зад }, k} \\
f_{r s}<\mu_{r s} \text { for all channels }(r, s) \\
\mu_{r s} \in D
\end{gathered}
$$

$$
P L R_{k}\left(\left\{\mu_{r s}\right\},\left\{f_{r s}\right\} \leq P L R_{k, \text { за }}, \quad k=\overline{1, K}\right.
$$

where $P L R_{k}\left(\left\{\mu_{r s}\right\},\left\{f_{r s}\right\}\right.$ is a rate of lost packets for k-th class of flow,

$P L R_{k з а д ~}$ is a given constraint on this value.

This problem belongs to a class of so-called NPdifficult optimization problems. For its solution modified genetic algorithm is elaborated and investigated.

\section{Modified Genetic Algorithm for NG Network Synthesis}

As it's well known GA consists of three procedures: crossover, mutations and selection].

But in this problem crossover and mutation procedures are made adjustable, so that strategic parameters are adapted in the process of algorithm run.

Define a channels matrix $K=\left\|k_{i j}\right\|$, where $k_{i j}=\left\{\begin{array}{c}1, \exists(i, j) \\ 0, \neg \exists(i, j)\end{array}\right.$, for each structure .

Then generate initial population of $n$ different structures in a given structures class - multiconnected structures with connectivity factor 2 . 

[2].

For synthesis we'll use semi-uniform crossover

Parent structures for crossover we select randomly with probability inverse-proportional to a cost function $C_{\Sigma}\left(\mathrm{E}_{\mathrm{i}}(\mathrm{k})\right)$, to each parent matrix corresponds $K^{i}, i=1,2$.

In the process of semi-uniform crossover each offspring gets one-half of parents' genes.

Crossover mask is represented as a matrix of the following form $M=\left\|m_{i j}\right\|$, where $m_{i j}=\left\{\begin{array}{l}0, p \geq p 0 \\ 1, p<p 0\end{array}\right.$,

$p 0=0.5-$ is a parameter, and a $p \in[0,1]$ is random.

Formally this process of crossover may be written as follows

$$
E(k)^{\prime}=\left\|e(k)_{i j}^{\prime}\right\|=\left\{\begin{array}{l}
(i, j)^{1}, k_{i j}{ }^{1}=1, m_{i j}=0 \\
(i, j)^{2}, k_{i j}{ }^{2}=1, m_{i j}=1
\end{array}\right.
$$

During crossover we generate two offsprings due to goal of maximization of algorithm productivity. In case of getting isolated subgraphs connect them with direct channels to a root.

Further for obtained offsprings - structure E(k)' solve the following problems channels capacities assignment and flows distribution (problem CA-FD) and find new channels capacities and flows distributions for all classes of service [1]. Its statement and solution algorithm are described below.

\section{Problem of optimal capacities choice and flows distribution}

\section{Problem statement}

MPLS network structure is given as an oriented $\operatorname{graph}_{G}=(X, E)$, where $X=\left\{x_{j}\right\} j=\overline{1, n}$ is a set of nodes (routers), $E=\{(r, s)\}$ is a set of channels, set of channels capacities $D=\left\{d_{1}, d_{2}, \ldots, d_{k}\right\}$ and their costs of unit length $C=\left\{c_{1}, c_{2}, \ldots, c_{k}\right\}$ are given

Let it also be given demand matrices of input flows of corresponding classes $H=\left\|h_{i j}^{(k)}\right\|, i, j=\overline{1, n}, k=\overline{1, K}$ and constraints on average packets delay for the $\mathrm{k}$-th flow $T_{c p, k}, k \in K_{1} \subset K$, and the constraint on packets loss ratio for different classes of flows.

It's required to choose such channels capacities $\left\{\mu_{r s}^{(0)}\right\}$ and to find the flows distributions of all the classes $F(k)=\left[f_{r s}(k)\right]$ for which total cost of NG network would be minimal and the established constraints on given values of QoS be fulfilled completely: The mathematical model takes the following form (8)-(10):

find

$$
\min C_{\Sigma}=\sum_{(r, s) \in E} C_{r s}\left(\mu_{r s}\right)
$$

under constraints

$$
T_{c p, K}\left(F(k), \mu_{r s}\right) \leq T_{\text {зад }, k} k=\overline{1, K},
$$

$$
\operatorname{PLR}\left(F_{k}\right) \leq P L R_{k, \text { зад }}
$$

\section{Algorithm of optimal capacities choice and flows distribution for NGN}

It consists of preliminary stage and finite number of iterations.

At the preliminary stage find initial channels capacities $\left\{\mu_{r s}(0)\right\}$ and flows distribution of all classes $F(k)$. Then go to the first iteration.

\section{$(I+1)$ iteration}

Let $I$ iterations be already performed and current capacities $\left\{\mu_{r s}(I)\right\}, \quad$ flows distributions $F_{k}(I)=\left\lfloor f_{r s}^{(k)}(I)\right\rfloor$ and total network cost $C_{\Sigma}(I)$ were found.

The goal of iteration $(1+1)$-is the optimization of channels capacities and flows distribution by criterion of total cost minimization $C_{\Sigma}$ and check of optimality condition.

1. For given values of capacities $\mu_{r s}(I)$ solve the problem FD and find new flows distributions of all classes:

$F_{(k)}(l+1)=\left[f_{r s}^{(k)}(l+1)\right] k=\overline{1, K}$.

2. For new flows $F_{(k)}(I+1)$ solve the problem of optimal capacities choice (CC) and find new channels capacities $\left\{\mu_{r s}(I+1)\right\}$ and total network cost

$C_{\Sigma}(I+1)=\sum_{(r, s) \in E} \mu_{r 0} C_{r s}(I+1) \cdot$

3. Compare If $\left|C_{\Sigma}(I)-C_{\Sigma}(I+1)\right|<\varepsilon$,

where $\varepsilon$ is given accuracy, then end of algorithm.

Found capacities $\left\{\mu_{r s}(I+1)\right\}$ and flows distribution of all classes $F_{k}(I+1)$ are optimal,

otherwise $I=I+1$ and go to the next iteration.

Then after comparison cost value for offspring and parents the we decide whether to introduce or not offspring structure $\mathrm{E}(\mathrm{k})$ ' in a sequence of locally efficient structures in current population) $\Pi$.

After crossover it's necessary to define mutation procedure. Note that basic algorithm suggested in a previous work [1] used the unconditional mutation procedure. Mutations consist of deleting or introducing some new channels in network structure. In the process of algorithm improvement the following schemes of mutations probability changes were suggested: 
- deterministic and adaptive change.

In deterministic version mutation probability is defined with application of time-variable function.

As an example we may change probability as follows

$$
\sigma(t)=1-c t / T .
$$

Note as time passes the probability decreases.

The main properties of such approach are

- mutation probability change doesn't depend on the success of its application in genetic search;

- a designer fully controls the probability changes due to certain formula;

- ) mutation probability change is fully predictable.

\section{Adaptive approach}

For the implementation of adaptive approach of mutation probability change we use so-called Rechenberg adaptation rule [2].

In this case the mutation probability as follows

$$
\sigma(t)=\left\{\begin{array}{c}
\sigma(t-1) / \lambda \text { if } \varphi(t-1)<\frac{1}{5} \\
\sigma(t-1) \lambda \text {, if } \varphi(t-1)>\frac{1}{5} \\
\sigma(t-1), \text { if } \varphi(t-1)=\frac{1}{5}
\end{array}\right\}
$$

where $\varphi(t)$ is a percent of good mutations and $\lambda=1.1$ is a learning factor.

Note that the main properties of this approach are the following:

1) mutation probability change depends on the successfulness of its application in the process of genetic search

2) mutation probability change is non-predictable. Self-adjustable mutation.

Self-adjustable mutation may be implemented on the level of chromosome (for each network structures) and on the level of genes (channels).

For this mutation probability change rule (law) $\sigma(t)$ should be given,

and then $\sigma(t)$ is coded in chromosome as :

$$
\{E k, \sigma(t)\} \text { or }\left\{E k=\left\|e k_{i j}\right\|,\left\|\sigma_{i j}(t)\right\|\right\} \text {. }
$$

But this approach leads to crucial decrease in algorithm productivity and for our problem is not good alternative. Note that main properties of such approach are the following:

1) mutation probability change is a result of natural choice;

2) the designer practically doesn't control this process;

3) mutation probability change is non-predictable.
As a contra version to scheme with unconditional crossover and dynamic mutation the scheme with unconditional mutation and dynamic crossover was suggested and implemented.

In the process of algorithm improvement with unconditional mutation the following schemes of crossover probability change were investigated:

- deterministic;

The implementation of deterministic scheme is based on hypotheses that on various search stages crossover may be more or less significant/ that's why as a function of crossover probability change is reasonable to choose non-monotonic function like such: e.g. $\sigma(t)=|\sin (t)|$, where $0 \leq t \leq T$.

- adaptive.

Define adaptive crossover as an operator probability of which decreases if a population is homogenous and increases if the population is sufficiently heterogeneous one. As a measure of homogeneity/heterogeneity take

$$
\begin{aligned}
& C_{\Delta}=\max \left(C_{\Sigma}\left(E_{i}(k)\right)-C_{\Sigma}\left(E_{j}(k)\right),\right. \\
& i \in[1, \ldots, n], j \in[1, \ldots, n], i \neq j, \\
& \text { where } n=3 \text { is a population size. }
\end{aligned}
$$

It's reasonable to suppose that in case of very like species in population crossover will be inefficient and vice versa. Thus in adaptive approach the rule of crossover probability change takes the form

$$
\sigma(t)=\left\{\begin{array}{c}
\sigma(t-1) / \lambda \text { if } C_{s}<C^{*} \\
\sigma(t-1) \lambda \text { if } C_{s}>C^{*} \\
\sigma(t-1), \text { if } C_{s}=C^{*}
\end{array}\right\}
$$

where $C^{*}$ is a threshold value and $\lambda=1.1$ is a learning factor.

- Self-adjusting crossover.

$\sigma \sigma$

The implementation of self-adjusting crossover is not reasonable due to substantial decrease of algorithm productivity like self-adjusting mutation.

\section{Experimental investigations}

The experimental investigations of various modifications of GA were carried out in which the efficiency of different variants of crossover and mutation procedures were explored and compared. The problem to be solved was a global Ukrainian NGN network design. In process of experiments were varied sets of channels capacities, costs of unit channel length, demands matrices, given QoS values (PDT, PLR). 
After series of experiments were carried out the following results were obtained for different variants of crossover and mutation procedures:

1. the combination of unconditional crossover and dynamic deterministic mutation: this implementation proved to be one of the most successful- the increase of productivity in comparison with basic GA was up to $15 \%$.

This experiment confirmed the hypothesis that mutations play the essential role at the initial phase of search while at final stage the most efficient is to use crossover for finding optimal ( or quasi-optimal) solution on the base of earlier obtained solutions.

2. the combination of unconditional crossover and dynamic adaptive mutation:

This combination did not allow reaching stable decrease of algorithm run time.

3. the combination of unconditional crossover and dynamic self-adjusting mutation:

this implementation is unreasonable as it essentially complicates the process of genetic search and leads to decrease of algorithm productivity.

4. dynamic deterministic crossover:

this implementation did not allow to obtain the stable increase in productivity.

5. dynamic adaptive crossover an unconditional mutation:

this implementation of GA proved to be the most successful- the productivity increase is $20-22 \%$.

So the hypothesis that crossover operator has some positive properties which mutation operator does not have is confirmed.

But it is worth to note application of crossover operator is efficient only if the species in population are quite different.

The GA with dynamic adaptive crossover and unconditional mutations was implemented in corresponding software kit and used for optimal structure design of global network.

As the illustration of experiments on the Fig.1 the initial structure of NG network in Ukraine is presented, while on the Fig. 2 one of the optimal structures is presented obtained by the suggested modified genetic algorithm which uses the combination of dynamic adaptive crossover and unconditional mutation.

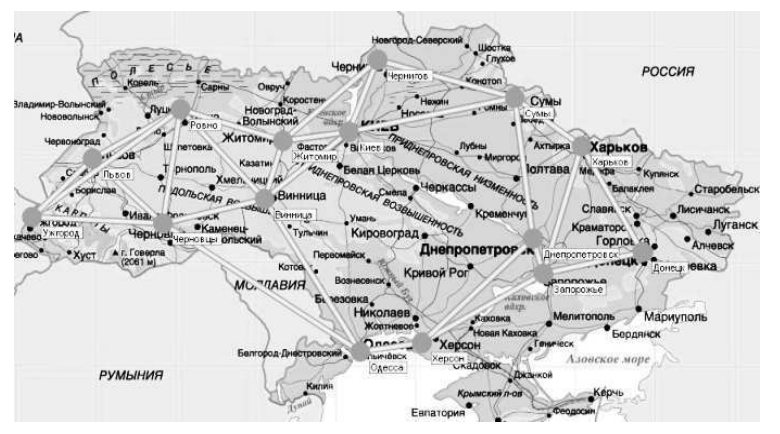

Fig.1. Initial MPLS network structure

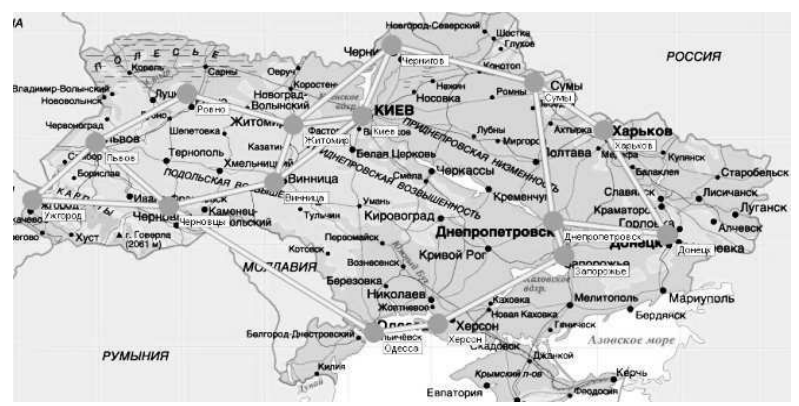

Fig. 2. Optimized MPLS network structure

These results were obtained with test data close to real data.

Note that after the application of modified GA total cut in network costs for optimized network structure comprised:

14250 thousandUSD -10023 thousandUSD = 4227 thousand USD,

that is by $30 \%$ less than the costs of initial network structure. It's very important that algorithm productivity was increased: this result was obtained with $22 \%$ less time than by basic GA.

\section{Conclusion}

The problem of new generation computer networks structure optimal design under constraints on given QoS values is considered.

For its solution different genetic algorithms for its solution with various modifications of crossover and mutation procedures were suggested and investigated.

The most efficient GA for NGN structure synthesis under constraints on given QoS was determined and its application for Ukrainian MPLS network topological design is presented.

\section{References}

1. Helen Zaychenko, Yu. Zaychenko. MPLS Networks: Modeling, analysis and Optimization. NTUU “KPI”, 2008.-240 p. ( In Russian)

2. Zaychenko Yuriy, Gasanov Aydin,Hamidov Galib. New Generation Networks performance analysis and Optimization. Proceedings of 10-th International conference "Application of Information and Communication Technologies- AICT 2016. 12-14 october, Baku, Azerbaijan.- pp. 206209.

3. Mikhail Z. Zgurovsky, Yuriy P. Zaychenko. Fundamentals of Computational Intelligence: System Approach. Studies in omputational Intelligence,. Vol. 652.-2016.- Springer AG. Switzerland- 375 p.

4. Helen Zaichenko, Yuriy Zaychenko.Algorithmic and Software Tools for Optimal Design of New Generation Computer.Lecture Notes in Communications and Computer Networks.-Springer Verlag, Switzerland.2016 


\title{
Зайченко О.Ю., Зайченко Ю.П.
}

\author{
Структурний синтез мереж нового покоління із застосуванням модифікованого генетичного \\ алгоритму
}

Проблема. Розглядається проблема структурного синтезу мереж нового покоління при обмеженнях на показники якості обслуговування (QoS) різних класів користувачів: середній час затримки пакетів та частку втрачених пакетів. При цьому необхідно, крім синтезу структури одночасно вибрати пропускні спроможності каналів зв'язку та знайти розподілення потоків всіх класів користувачів з урахуванням обмежень на показники QoS. Ця задача відноситься до класу так званих NP-важких задач комбінаторної оптимізації для яких відсутні точні алгоритми поліноміальної обчислювальної складності. Тому в работі пропонується модифікований генетичний алгоритм (ГА) її вирішення.

Мета досліджень. Дослідити різні варіанти генетичних алгоритмів: детермінованих, адаптивних та тих, що самоналаштовуються та оцінити їх ефективність для вирішення проблеми структурної оптимізації мереж.

Методика реалізації. В результаті аналізу літератури 3 генетичних алгоритмів було виділено класи алгоритмів, що відрізняються варіантами адаптації стратегічних параметрів алгоритмів- ймовірностями кроссовера та мутацій. Розглядались різні методи адаптації-цих параметрів: детерміновані, адаптивні та самоналаштовуючі.

Результати досліджень. В процесі експериментів були досліджені наступні варіанти ГА:

- $\quad$ комбінація безумовного кроссовера та динамічної детермінованої мутації,

- $\quad$ комбінація безумовного кроссовера та динамічної адаптивної мутації ;

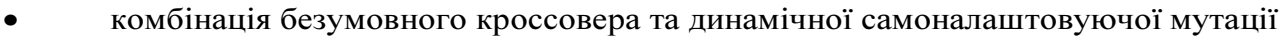

- комбінація детермінованого динамічного кроссовера та динамічної мутації;

- $\quad$ комбінація динамічного адаптивного кроссовера та безумовної мутації.

Висновки. В результаті досліджень було встановлено, що найбільш ефективним є генетичний алгоритм 3 динамічним адаптивним кросовером та безумовною мутацією.

Цей алгоритм було реалізовано програмно та використано для вирішення конкретної задачі синтезу структури глобальної комп'ютерної мережі та оцінено його ефективність.

Ключові слова: мережі нового покоління; показники якості сервісу; структурний синтез мережі; адаптивний генетичний алгоритм.

\section{Зайченко Е.Ю., Зайченко Ю.П.} алгоритма

Структурный синтез сетей нового поколения с применением модифицированного генетического

Проблема. Рассматривается проблема структурного синтеза сетей нового поколения при ограничениях на показатели качества обслуживания различных классов пользователей (Quality of Service -QoS)- cpeднеe время задержки доставки пакетов и среднюю долю потерянных пакетов. При этом необходимо кроме выбора структуры сети одновременно выбрать пропускные способности всех каналов связи и найти распределение потоков всех классов пользователей с учетом ограничений на QoS. Данная задача относится к классу так называемых NPтрудных задач комбинаторной оптимизации для которых отсутствуют точные алгоритмы полиномиальной вычислительной сложности. Поэтому в работе предлагается модифицированный генетический алгоритм ее решения.

Цель исследований. Исследовать различные варианты построения генетических алгоритмов детерминированных, адаптивных и самонастраивающихся и оценить их эффективность для решения проблемы структурной оптимизации.

Методика реализации. На основании анализа литературы по генетическим алгоритмам были выделены классы алгоритмов, отличающиеся вариантами адаптации стратегических параметров алгоритмов- вероятностями кроссовера и мутаций. Рассматривались различные комбинации способов адаптации- детерминированные, адаптивные и самонастраивающиеся.

Результаты исследований. Были исследованы следующие варианты ГА :

- $\quad$ комбинация безусловного кроссовера и динамической детерминированной мутации;

- комбинация безусловного кроссовера и динамической адаптивной мутации;

- комбинация безусловного кроссовера и самонастраивающейся мутации;

- $\quad$ комбинация детерминированного динамического кроссовера и динамической мутации;

- $\quad$ комбинация динамического адаптивного кроссовера и безусловной мутации.

Выводы. В результате исследований было установлено, что наиболее эффективным для задачи структурного синтеза сетей является генетический алгоритм с динамическим адаптивным кроссовером и безусловной мутацией. Этот алгоритм был реализован программно и использован для конкретной задачи синтеза структуры глобальной компьютерной сети и оценена его эффективность

Ключевые слова: сети нового поколения; показатели качества сервиса; структурный синтез сети; адаптивный генетический алгоритм. 